\title{
Michael Bollig, Shaping the African Savannah. From Capitalist Frontier to Arid Eden in Namibia
}

\author{
Cambridge, Cambridge University Press 2020. ISBN 978-1-108-48,848-8 (Hardback). \\ $\mathrm{XIII}+404$ pages, index
}

\author{
Eduard Gargallo ${ }^{1}[$
}

Accepted: 28 May 2021 / Published online: 8 June 2021

(c) The Author(s), under exclusive licence to Springer Science+Business Media, LLC, part of Springer Nature 2021

In this important new book, Michael Bollig provides an environmental history of the Kaoko region in North-Western Namibia while contributing to wider debates on colonialism, conservation, and land-use in Africa. Bollig has had a long research career based in North-Western Namibia (as well as in East Africa) which he pulls together in Shaping the African Savannah, sharing a wealth of knowledge and insights on the region's populations and environment. This book builds on the excellent works on Kaoko by Miescher and Henrichsen (2000), Rizzo (2012), Friedman (2011), and Van Wolputte $(2007,2013)$. It is also situated within larger African literature dealing with localized environmental histories (Bolaane 2013; Bender Shetler 2007; Brockington 2002; Carruthers 1995). Bollig's study is especially interesting as it covers the Kaoko region in its entirety rather than focusing on a single Protected Area (PA), as is typically the case in much of the above literature. In this, he adds to a recent trend in Namibian environmental regional histories, most notably Lenggenhager (2018) for the Caprivi/Zambesi and Kreike (2013) for the former Owamboland. Shaping the African Savannah is a well-researched and detailed account of the recent history and ecology of the Kaoko region and is essential reading for those both within the academic and non-academic scene (e.g., NGOs) interested in conservation, environmental history, colonialism, common management of resources and new frontiers of investment in African drylands.

One of the strongest points of the book is its time-depth. Beginning with the pre-history of the region and finishing

Eduard Gargallo

egargallo@yahoo.com

1 Centro de Estudos Internacionais, Instituto Universitário de Lisboa (ISCTE-IUL), Lisboa, Portugal just before the COVID-19 pandemic, Bollig's historical overview illustrates an ever-changing landscape that challenges the allegedly primitive or "natural" state of its environment. Following calls by Hodder (2014) to avoid the duality of human/nature inferences and using the concept of "environmental infrastructure" developed by Kreike (2013), he presents a masterful narrative integrating both biophysical or "natural" processes and human interventions that shape the Kaoko landscape. For example, he highlights the role of elephants in the history of the region, not only as sources of ivory for international trade, but also as shapers of the landscape and influencing patterns of human settlement and economic activities.

In chronologically ordered chapters, Bollig takes us through Kaoko's history. Following a description of the deep history of the region and the emergence of pastoralism, he focuses on the late nineteenth and early twentieth centuries, when intensive game hunting, especially of elephants, by both local and outside hunters significantly changed local environments. This period was followed by the gradual incorporation of Kaoko into the South West African colonial system, specifically under the South African mandate. In a process of what Bollig calls "encapsulation", Kaoko became framed as a wilderness where outside economic exchanges were severely curtailed. Bollig explores the environmental feedbacks from these various events, for example how the ending of internal raids, the arrival of Angolan refugees, and the reduction in game resulted in an increase of livestock numbers and the expansion of gardening. From this developed the encapsulated Kaoko, based on the strict control of the mobility of people and livestock inside and outside the region. In the official view, Kaoko became marked as a wilderness inhabited by 'traditional' African herders.

By the 1950s, through modernization programs led by proponents in apartheid South Africa, the expansion of 
boreholes for cattle grazing and other measures were taken to increase cattle numbers in Kaoko. As Bollig points out, increasing boreholes often led to year-round availability of water resources and concentrated grazing regimes. Throughout this period, colonial policies remained contradictory: pastoral expansion was accompanied by fear of overgrazing and modernization programmes were at odds with the reinforcement of Traditional Authorities.

Throughout the 1960s and 1970s, despite growing environmental concerns at the international level - and in some sectors within South African society - a growing pastoral economy was prioritised. The administration in Kaoko remained firmly anti-conservation and several proposals to expand protected areas were not pursued. The later famous environmentalist Garth Owen Smith advocated for a combination of agropastoralism, wildlife, and limited PAs, but this rhetoric remained outside of official policies. In the 1980s the elimination of game intensified due to widespread poaching amid the Namibian War of Independence. All of this was accompanied by a drastic fall in livestock numbers during the extreme droughts of 1980-82.

Independence in 1990 ushered in a new era in Kaoko. Livestock had already begun to recover during the late 1980s and for the next two decades growth was sustained, as climate conditions were favourable and more boreholes were built. Contrary to the rangeland's disequilibrium model a common theory that grazing pressure has no significant effect on grass-herb cover, Bollig's research in Kaoko proves that it does: areas of intensive grazing near water points (e.g., boreholes) or water courses experience change from palatable and perennial to less palatable, grazing-tolerant species and annual grasses, not to mention the effects of variations in fire regimes on vegetation. Trends towards increasing numbers of livestock did not stop until a series of severe droughts in the 2010s. In recent years conflicts over grazing systems and territoriality have intensified as more people move into the region (e.g., Owambo-speaking herders arriving from the east). Currently, increasing numbers of people are resorting to State law and courts to resolve these difficulties and are calling for a "neater definition of grazing territories."

Bollig reviews how Kaoko has recently witnessed the expansion of new common management institutions. For example, Communal Conservancies that devolve limited powers over wildlife and conservation-related income have spread in the region, and in some cases has led to the rapid recovery of species - such as elephants - thus bolstering a tourism economy. He outlines how Kaokolanders have embraced the Conservancies' program in the expectation that the revenue will contribute to their livelihoods and control over their lands. On the other hand, water supply has also been devolved and decentralized. Boreholes are now managed by Water Point Associations (WPAs) and fees charged to local users.

Bollig's critical review and research on the history and ecology of Kaoko provides fascinating fodder for larger debates about conservation, environment, common management of resources, and outside investments, among others, in rural Africa. He highlights how, "Decades before the Kaokoveld became part of the German Empire, global value chains embedded in the capitalist world system affected local social-ecological relations," while "colonialisation brought about a rupture of capitalist expansion." He presents a strong argument that present-day trends towards the region's commoditization and international market integration are part of a longer history pre-dating colonial interventions. Ironically, he also argues that some colonial interventions in the last century may in fact have hampered modern capitalist expansion.

Bollig provides an interesting description how the commons in Kaoko are being reorganized through State and international policies and norms, rather than being privatized or divided. The Conservancies' program has "deeply infiltrated institutions of local resource management" and brought an "expansion of the state," but has simultaneously fed resistance against state initiatives and national elites. Despite some impactful changes to social-ecological governance models, he argues that it is doubtful that Kaoko is experiencing a complete commodification of land, as customary rules enforced by Traditional Authorities continue to apply in core areas, and no known instances of "green grabbing" have been detected. In contrast to Ostrom's view that common management of resources tends to support the interests of the majority, he notes that Water Point Associations' management devolution has led to rules that favour a small number of wealthy livestock owners over the majority of less affluent herders.

In his final chapter, Bollig presents possible future scenarios for Kaoko together with the latest developments in the region: incipient mining exploration, the revival of the Epupa dam project, the extension of Community Based Natural Resource Management to livestock management, the advocacy for greater "social transfers," and the impact of climate change. He sees two possible trends, one that includes "a progressive ethnicization of resource governance" and calls for "exclusive rights of administration and management based on ethnic affiliation," and one that is based on "the development of institutions of co-management and public-private partnerships." He declares that "in many ways both social change scenarios are contradictory," in that the first seeks encapsulation and the latter aims at "linking local institutions, actors, and practices with national and international frameworks." I am not sure that I agree this is in fact a contradiction. Both in Namibia and elsewhere conservation NGOs and policies have been formulated in conjunction 
with ethnic, traditional, or indigenous movements. Bollig himself shows how Kaoko's TAs see their claims "as potentially in harmony with conservation." True, we should avoid any romanticized views of communities under traditional authority being necessarily responsible guardians of their environments. And it is also true that Bollig is aware that Kaoko leaders, if faced with conservation goals that conflict with their own interests "... will not cling to the conservation paradigm but will opt for solutions that best further their ends." Indeed, clashes between TAs and Conservancies are not new in Namibia. But the possibility of diverging agendas between Traditional Authorities and conservation institutions does not necessarily imply a contradiction between ethnic mobilization and conservation initiatives, nor is the first always isolationist and the latter internationalist. But as I noted earlier, this is just one of the many issues that Bollig's book compels us to revisit and reconsider.

\section{References}

Bender Shetler, J. (2007). Imagining Serengeti: A History of Landscape Memory in Tanzania from Earliest Times to the Present, Ohio University Press, Athens.

Bolaane, M. (2013). Chiefs, Hunters and San in the Creation of the Moremi Game Reserve, Okavango Delta: Multiracial Interactions and Initiatives, 1956-1979, National Museum of Ethnology, Osaka.
Brockington, D. (2002). Fortress Conservation: The Preservation of the Mkomazi Game Reserve, Kames Currey, Oxford.

Carruthers, J. (1995). The Kruger National Park. A Social and Political History, University of Natal Press, Pietermaritzburg.

Friedman, J.T. (2011). Imagining the Post-Apartheid State: An Ethnographic Account of Namibia, Berghahn, Oxford.

Hodder, I. (2014). The Entanglements of Humans and Things: A LongTerm View. New Literary History 45: 19-36.

Kreike, E. (2013). Environmental Infrastructure in African History: Examining the Myth of Natural Resource Management in Namibia, Cambridge University Press, Cambridge.

Lenggenhager, L. (2018). Ruling Nature, Controlling People. Nature Conservation, Development and War in North-Eastern Namibia since the 1920s, Basel Afrika Bibliographien, Basel.

Miescher, G. \& Henrichsen, D. (eds). (2000). New Notes on Kaoko. The Northern Kunene Region (Namibia) in Texts and Photographs, Basler Afrika Bibliographien, Basel.

Rizzo, L. (2012). Gender and Colonialism. A History of Kaoko in north-western Namibia 1870s-1950s. Basler Afrika Bibliographien, Basel.

Van Wolputte, S. (2007). 'Cattle Works: Livestock Policy, Apartheid and Development in Northwest Namibia, c. 1920-1980'. African Studies 66: 103-28.

Van Wolputte, S. (2013). 'Vicious Vets and Lazy Locals: Experimentation, Politics and CBPP in North-West Namibia, 1925-1980'. Journal of Namibian Studies. 13: 79-100.

Publisher's Note Springer Nature remains neutral with regard to jurisdictional claims in published maps and institutional affiliations. 